\title{
Regulating Vessel Biofouling to Support New Zealand's Marine Biosecurity System - A Blue Print for Evidence-Based Decision Making
}

\author{
Eugene Georgiades ${ }^{1 *}$, Daniel Kluza1 ${ }^{1}$,Tracey Bates ${ }^{1}$, Katie Lubarsky', Jennie Brunton', \\ Abraham Growcott ${ }^{1}$, Trecia Smith ${ }^{2}$, Simon McDonald ${ }^{3}$, Brendan Gould ${ }^{1}$, Naomi Parker ${ }^{2}$ \\ and Andrew Bell ${ }^{2}$
}

${ }^{1}$ Biosecurity New Zealand, Ministry for Primary Industries, Wellington, New Zealand, ${ }^{2}$ Ministry for Primary Industries, Wellington, New Zealand, ${ }^{3}$ Agriculture and Investment Services, Ministry for Primary Industries, Wellington, New Zealand

A healthy marine environment is integral to numerous New Zealand economic, social, and cultural values, including fisheries, aquaculture, tourism, and recreational and customary activities. The introduction and spread of marine non-indigenous species (NIS) via the vessel biofouling pathway may put these values at risk. Over the past two decades, the Ministry for Primary Industries (MPI) has been proactive in commissioning research focused on the risks associated with vessel biofouling, identification of potential risk vessels, and risk management options. In 2010, MPI consulted on options to manage the biofouling risks on all vessels entering New Zealand waters. In 2014, New Zealand became the first country to introduce mandatory biofouling requirements. Between 2014 and 2018, MPI focused on communicating the requirements to support stakeholder awareness, readiness, and uptake. In parallel, MPI commissioned further research to investigate proactive and reactive approaches to biofouling management. Research outcomes were summarized and technical advice provided to inform stakeholders of what constitutes best biofouling management practices. This review summarizes MPl's research and technical advice on the risks associated with vessel biofouling and its management, and the procedures followed to produce New Zealand's biofouling regulations. The development of these regulations is also contextualized in terms of New Zealand's marine biosecurity system. The transparent and evidencebased approach followed by MPI provides a blueprint for establishing biofouling regulations. Because these regulations are aligned with the International Maritime Organization guidelines, there is the potential to develop consistent global and domestic practices for managing marine NIS introduction and spread.

Keywords: biofouling, biosecurity, New Zealand, marine, non-indigenous species, pathway approach

\section{INTRODUCTION}

\section{What Are We Protecting?}

A healthy marine environment is critical to the world's economic, environmental, and sociocultural values. As such, the impacts posed by the introduction and spread of marine nonindigenous species (NIS) associated with vessels are a global concern (International Maritime Organization [IMO], 2017c; Food and Agriculture Organization of the United Nations [FAO], 2018; Carlton et al., 2019). 
New Zealand's marine environment is a global biodiversity hotspot, containing a substantial amount $(\sim 80 \%)$ of the country's biodiversity (New Zealand Government, 2000). Further, endemic species account for $>50 \%$ of known marine species (Costello et al., 2010). The majority (>90\%) of New Zealand's population live within $50 \mathrm{~km}$ of the coastline, with $>60 \%$ residing within $5 \mathrm{~km}$ (Statistics New Zealand, 2015a,b), hence the marine environment serves as a hub for many recreational activities (Allen et al., 2009). Māori regard the marine environment as a tāonga (treasured possession), which is integral to their culture, identity, spirituality, and mythology (Moon, 2015). This environment is important to tangata whenua (indigenous people; born of the land) by providing sustenance, with the mana (prestige, status) of hapu (kinship group) and iwi (large kinship group) based on the provision of hospitality in the form of kaimoana (seafood, shellfish) (Morgan, 2006; Wehi et al., 2013). The export revenue generated from New Zealand's wild and cultured fisheries is \$NZD 1.8 billion (Ministry for Primary Industries New Zealand [MPI], 2019). Further, the New Zealand Government's aquaculture strategy supports this industry's goal to grow to $\$$ NZD 3 billion in annual sales by 2035 (New Zealand Government, 2019).

The diverse range of ecosystems contained within New Zealand's marine environment provides a range of suitable habitats for the establishment and spread of marine NIS (Inglis, 2001; Beaumont et al., 2008). The potential to introduce and spread NIS is centered on activities within coastal areas such as shipping and boating (e.g., Floerl et al., 2009; Ferrario et al., 2017). Moreover, conditions that favor the establishment of NIS are created by human impacts on this environment (e.g., pollution, sedimentation, and anthropogenic structures) (e.g., Crooks et al., 2011; McKenzie et al., 2012; Simkanin et al., 2012).

There is a long history of vessels being identified as vectors of NIS introduction and spread (Chilton, 1910; Allen, 1953; Skerman, 1960). However, it wasn't until the latter part of the 20th century that the risks associated with the translocation of marine NIS were widely recognized (e.g., Carlton and Geller, 1993). New Zealand annually receives $>3,000$ vessel arrivals which transport 98\% of traded goods (Inglis, 2001; New Zealand Customs Service [NZCS], 2008, 2010), and significant economic benefits are derived from marine service provision (Inglis et al., 2012).

International vessels arrive to New Zealand throughout the year, with peak activity occurring during spring and summer due to the influx of recreational and cruise vessels (Inglis et al., 2012). The major sources of marine biosecurity risk associated with international vessel arrivals are ballast water discharges and biofouling. Managing these risks is the role of the Ministry for Primary Industries ${ }^{1}\left(\mathrm{MPI}^{2}\right)$, New Zealand's lead government agency for managing biosecurity. The Biosecurity Act 1993 (New Zealand Parliament, 1993) is the legal framework that

${ }^{1}$ Formerly Department of Agriculture; Ministry of Agriculture and Fisheries; Ministry of Agriculture; Ministry of Agriculture and Forestry/Biosecurity New Zealand; Ministry of Agriculture and Forestry.

${ }^{2}$ https://www.mpi.govt.nz/ enables MPI to manage the arrival and establishment of NIS through the development of science- and risk-based regulations.

In addition to the Biosecurity Act, the management of marine NIS in New Zealand's domestic environment is governed by a variety of legislation ${ }^{3}$ and policies, including but not limited to: the Resource Management Act (1991), New Zealand Coastal Policy Statement, Maritime Transport Act (1994), the Resource Management (Marine Pollution) Regulations (1998), the Hazardous Substances and New Organisms Act (1996), and the Exclusive Economic Zone and Continental Shelf (Environmental Effects) Act (2012). Agencies responsible for administering these legislation include the Department of Conservation, Maritime New Zealand, Environmental Protection Authority, and regional councils (i.e., local government). Use of the above legislation and policies to manage marine domestic pathways was reviewed by Sinner et al. (2013).

\section{Ballast Water}

Until recently, ballast water was widely considered the most significant pathway for marine vessel-based NIS translocations due to the hypothetically extreme risk of successfully translocating an entire ecosystem (Carlton et al., 1995; Gollasch et al., 2002; Minton et al., 2005). Further, the advent of effective biocidal antifouling paints (particularly tributyltin-based paints) was considered to have managed vessel biofouling (Lewis, 2004). In 1998, MPI introduced mandatory measures to manage the risks associated with ballast water discharges from international vessel arrivals (Ministry for Primary Industries New Zealand [MPI], 2005). In 2004, the International Maritime Organization (IMO), the global regulatory authority responsible for safe, secure, and environmentally sustainable international shipping, adopted the International Convention for the Control and Management of Ships' Ballast Water and Sediments (International Maritime Organization [IMO], 2004). The Convention formally entered into force on September 8th 2017 (International Maritime Organization [IMO], 2017b) and requires risk management through the installation and use of ballast water treatment systems. The Convention is currently in a 5-year experience-building phase for the purpose of producing evidence-based amendments. With a few exceptions, all internationally trading vessels (i.e., ships that carry ballast water) will have to install a treatment system by 2024. Currently, eligible vessels must carry a ballast water management plan and record book, and an international ballast water management certificate (International Maritime Organization [IMO], 2017a).

New Zealand's ability to meet its obligations under international maritime agreements, e.g., the United Nations Convention on Law of the Sea (UNCLOS), the International Convention for the Safety of Life at Sea (SOLAS), and the International Convention for the Prevention of Pollution from Ships (MARPOL), are enabled by the Maritime Transport Act through Maritime New Zealand. Maritime New Zealand is the national agency responsible for the safety, security, and protection of coastal and inland waterways, and acts as Port State Control.

\footnotetext{
${ }^{3}$ http://www.legislation.govt.nz/
} 
New Zealand acceded to The Convention on June 13th 2018. New Zealand's obligations under The Convention were reflected in updates to the Maritime Transport Act (1994) (New Zealand Parliament, 1994) and Maritime New Zealand's Marine Protection Rules Part 300 (Maritime New Zealand, 2018).

\section{Biofouling}

In the late 1990's, the significance of vessel biofouling as a pathway for marine NIS translocations was becoming more apparent (James and Hayden, 2000; Ruiz et al., 2000; Hewitt et al., 2004). In New Zealand, it was determined that 69$90 \%$ of known marine NIS may have been introduced via vessel biofouling (Cranfield et al., 1998). Kospartov et al. (2008) later refined this figure to $\sim 87 \%$. Other jurisdictions, including parts of the United States (Eldredge and Carlton, 2002; Fofonoff et al., 2003), Australia (Hewitt et al., 2004) and Japan (Otani, 2006) also identified that the vessel biofouling pathway was likely responsible for the introduction of a large proportion of marine NIS.

Variations in biofouling type and amount have been long associated with vessel class, maintenance regime, and operational profile (Stubbings, 1947; Skerman, 1960; James and Hayden, 2000; Lewis, 2004). Hence, the biosecurity risk posed by vessel biofouling can vary between vessels, as well as being specific to each vessel both temporally and spatially. In the early 2000's, MPI identified the risk posed by biofouling on internationally arriving vessels to New Zealand values as a significant knowledge gap. As such, a two-pronged approach was applied to investigate the risks to New Zealand and to raise these initial concerns and MPI's ongoing research findings internationally through the IMO.

\section{BIOFOULING ON INTERNATIONAL VESSELS ARRIVING TO NEW ZEALAND}

To better understand and potentially manage vessel biofouling risks in a New Zealand context, MPI commissioned a research survey of internationally arriving vessels. The research objectives were to determine the:

- Identity (species), origin (native, NIS, cryptogenic) and extent of biofouling on vessels;

- Relationship between NIS presence and biofouling extent;

- Influences on NIS presence and biofouling extent (e.g., maintenance regimes and operational profile) (Inglis et al., 2010).

Between 2004 and 2007, 508 internationally arriving vessels were sampled, including recreational vessels $(n=186)$, fishing vessels $(n=3)$, passenger vessels $(n=49)$, and merchant vessels (i.e., bulk carriers, container vessels, tankers, etc.; $n=270)$. Vessels were sampled within 2 weeks of entering a New Zealand port (Inglis et al., 2010).

Findings from the research program demonstrated that:

- All major vessel types entering New Zealand are likely to be fouled;
- NIS were found on $\sim 60 \%$ of vessels, and $>30 \%$ of vessels had NIS that were unestablished in New Zealand;

- Of the 187 species identified, $>68 \%$ were NIS; of these, $73 \%$ were not yet established;

- $>37 \%$ of NIS were recorded on a single vessel, meaning that a much larger range of species may be arriving than captured by this research survey;

- There was a positive relationship between a vessel's biofouling extent and the number of NIS present;

- Biofouling primarily consisted of barnacles, tubeworms, bryozoans, bivalves, and macroalgae;

- Niche areas (including sea chests and hull appendages) were disproportionately fouled relative to the hull;

- Although most vessels surveyed carried out biofouling management activities, large variations in the predictability of fouling occurrence is indicative of significant variability in the quality of management applied;

- The risk factors associated with the presence of NIS differ among vessel types. NIS were more likely to be present on:

- Commercial vessels-the longer the time since last drydock, the older the vessel, and the greater the average number of days in port;

- Recreational vessels-the greater the average number of days spent in port, the longer the lay-up period, and the longer the dry-dock interval (Inglis et al., 2010).

Inglis et al. (2010) concluded that the identity, extent, and diversity of biofouling on individual vessels was difficult to predict with any certainty due to the complex dynamics of biofouling assemblages and vessel itineraries.

Further vessels were sampled subsequent to this study, including fishing vessels $(n=8)$ (Piola and Conwell, 2010), slowmoving vessels $(n=8)$, and an oil rig (Cawthron Institute, 2010).

\section{RISK ANALYSIS}

A risk analysis was conducted to determine the "biosecurity risks associated with biofouling organisms on vessels arriving to New Zealand" (Bell et al., 2011). This analysis followed MPI's risk analysis procedures (Ministry for Primary Industries New Zealand [MPI], 2006) which are consistent with international standards (Food and Agriculture Organization of the United Nations [FAO], 2007). This includes peer review by international experts.

As the number of species associated with vessel biofouling is substantial (Anderson et al., 2003; Minchin et al., 2006), 20 broad taxonomic groups were assessed in order to keep the analysis manageable. "For each group an initial hazard identification assessment determined whether a risk assessment was required. For groups identified as potential hazards, the following factors were assessed sequentially with a determination of non-negligible or negligible for each: the likelihood of entry, the likelihood of establishment, and potential consequences of establishment. The analysis of each group concluded with a risk estimation and the assessment of potential management options" (Figure 1; Bell et al., 2011). 

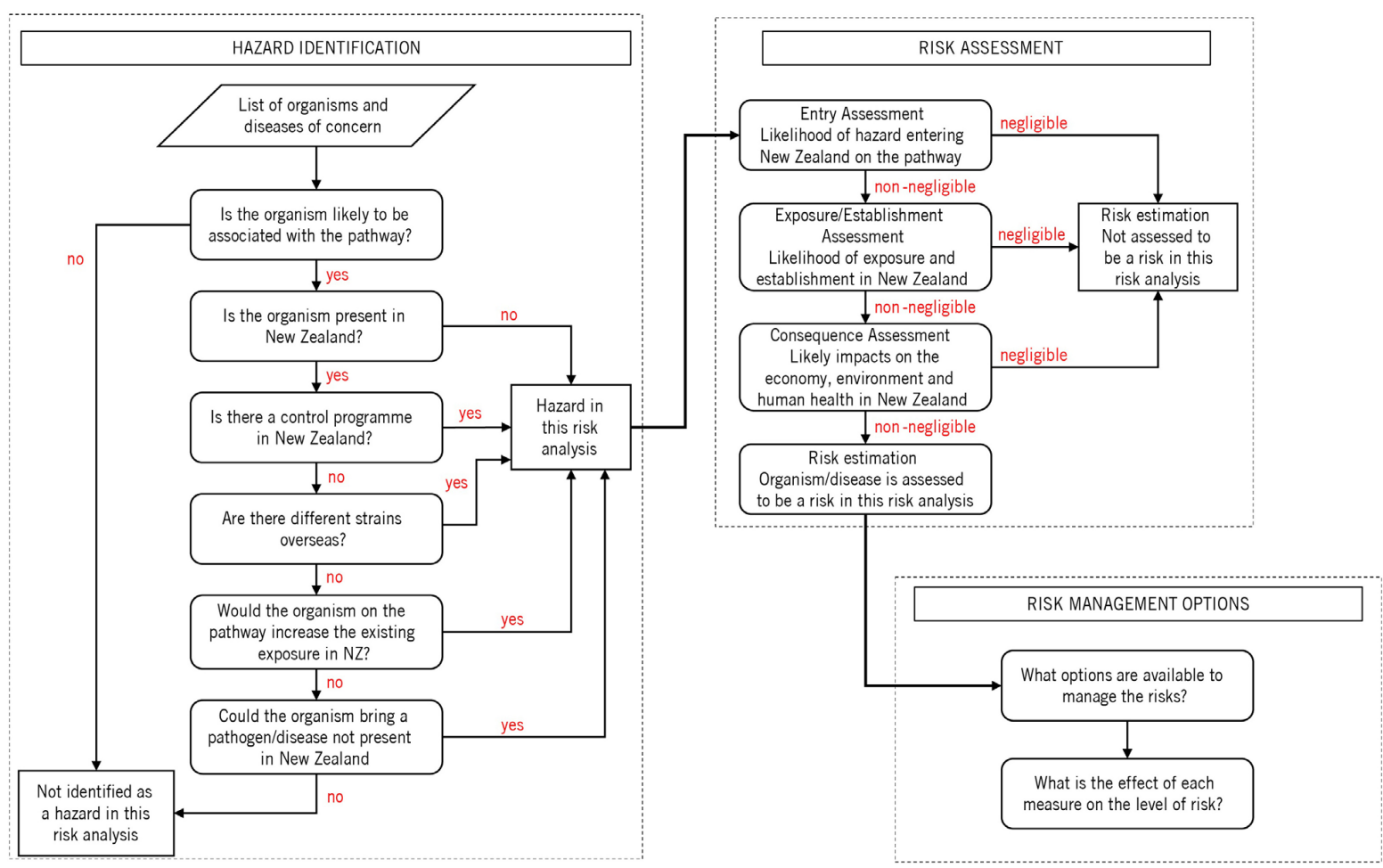

FIGURE 1 | Outline of the risk analysis process (Ministry for Primary Industries New Zealand [MPI], 2006).

Of the 20 broad taxonomic groups assessed, species within 12 groups represented non-negligible risks to New Zealand's core values (i.e., environmental, economic, and socio-cultural) and for which risk management measures could be justified (Table 1). The non-negligible risk groups contained organisms with the potential to impact upon economic values or ecosystem services. Although not all NIS may threaten New Zealand's core values, the difficulty in predicting the identity and impacts of future NIS was highlighted (Bell et al., 2011).

Based on the above outcomes, and recognizing the need for rapid border clearance of vessels, Bell et al. (2011) proposed that any macrofouling found on international vessels should

TABLE 1 | Broad taxonomic groups included within MPI's vessel biofouling risk analysis (Bell et al., 2011)*.

\begin{tabular}{|c|c|c|c|}
\hline \multicolumn{4}{|l|}{ Taxonomic group } \\
\hline $\begin{array}{l}\text { Amphipods and } \\
\text { isopods }\end{array}$ & Bryozoans & Hydroids & Round worms \\
\hline $\begin{array}{l}\text { Bacteria and } \\
\text { viruses }\end{array}$ & Crabs & Macroalgae & Ribbon worms \\
\hline Barnacles & Echinoderms & Microalgae & $\begin{array}{l}\text { Sea anemones } \\
\text { and corals }\end{array}$ \\
\hline Bivalves & Flatworms & Other Arthropods & Sea squirts \\
\hline Bristleworms & $\begin{array}{l}\text { Gastropods and } \\
\text { Chitons }\end{array}$ & Peanut worms & Sponges \\
\hline
\end{tabular}

*Species identified as a non-negligible risk to New Zealand's core values highlighted in bold. be treated as risk organisms that require management. The association of the presence of macrofouling with the introduction of NIS (Inglis et al., 2010), and difficulties in the in situ identification of marine organisms were provided as rationale for this recommendation.

The risk analysis demonstrated that vessel biofouling was a risk to New Zealand's marine environment, and, in doing this, highlighted a considerable biosecurity gap that necessitated management at a national and international level (Bell et al., 2011).

\section{INTERNATIONAL DEVELOPMENT OF BIOFOULING GUIDELINES}

The IMO is the major standard-setting body for marine biosecurity issues related to shipping. In 2007, New Zealand, along with the United Kingdom, Australia, the International Union for Conservation of Nature, and Friends of the Earth International succeeded in getting the development of management measures for biofouling on the agenda of the IMO Marine Environment Protection Committee. In 2008, MPI staff led an IMO "correspondence group" on biofouling-a group with representatives from 18 countries and nine non-governmental organizations, including industry peak bodies and conservation groups. This group worked between IMO sessions to summarize the current biofouling research, investigate potential impactspositive and negative - of biofouling regulations on industry and 
on the environment, and to identify best practice measures for managing biofouling. Based on this work, in 2009 the IMO agreed to develop international guidelines for managing biofouling on ships. These voluntary guidelines were adopted by the IMO in 2011, with the intention "to provide a globally consistent approach to the management of biofouling using best practice" (International Maritime Organization [IMO], 2011). Consistent with MPI's 2007-2012 strategic priority to "Lead and seek international support for the management of ballast water and biofouling," MPI's staff and commissioned scientific research played a prominent role in the development of the IMO guidelines.

\section{NEW ZEALAND STANDARD DEVELOPMENT}

Given the ongoing costs associated with response and control activities (discussed later), and the irreversible impacts that NIS can have on New Zealand's core values, MPI identified the prevention of entry and establishment of marine NIS as a key priority (Ministry for Primary Industries New Zealand [MPI], 2010d). Accordingly, in 2010 MPI consulted upon a proactive approach to manage the risks from biofouling on internationally arriving vessels. The consultation period for written submissions was from 6th May to 16th June 2010, and four stakeholder meetings were held around New Zealand.

The consultation package included:

- Consultation Paper - Managing and Controlling the Risk Posed to the Marine Environment from Biofouling on Arriving Vessels (Ministry for Primary Industries New Zealand [MPI], 2010d);

- Draft Import Health Standard for Vessel Biofouling (Ministry for Primary Industries New Zealand [MPI], 2010c);

- Draft Guidance Document in support of the Import Health Standard for Vessel Biofouling (Ministry for Primary Industries New Zealand [MPI], 2010a);

- Requirements for Hull Cleaning Facilities to be MPIApproved (Ministry for Primary Industries New Zealand [MPI], 2010b);

- Risk Analysis: Vessel Biofouling (Bell et al., 2011).

Ministry for Primary Industries New Zealand [MPI] (2010d) considered three options for managing the risk associated with vessel biofouling:

- Await an international solution;

- Voluntary measures for arriving vessels;

- Mandatory requirements for arriving vessels.

Options were assessed using the following criteria:

- Feasibility - is the option feasible and what is the probability of success?

- Resources - what resources, skills, and capabilities are required?
- Opportunities and Barriers - are there other opportunities or barriers to success, such as timing or the factors that cause public concern (coercion, equity, fear, etc.)?

- Net benefit - what is the overall net benefit of the option including costs, benefits, and their likelihoods?

- Strategic fit - how well does the option fit with the Government's strategies and MPI's Statement of Intent?

The overall net benefits of the first two options were considered to be negative. This was because any long-term benefit of international regulations would be outweighed by the uncertainty of the regulations being adopted (both if and when), and the consequences borne by New Zealand in the meantime. Further, voluntary measures would not provide a level playing field across stakeholders (i.e., those who voluntarily comply versus those who do not), would have an unknown level of compliance, and result in uncertainty regarding whether the risk would actually be managed (Ministry for Primary Industries New Zealand [MPI], 2010d).

"Mandatory requirements for arriving vessels" was the preferred option as their enforceable nature was more likely to result in a more rapid behavioral change to protect New Zealand's values. Further, this option would result in a level playing field across all stakeholders (Ministry for Primary Industries New Zealand [MPI], 2010d).

The principal component of the proposed biofouling regulations was vessels arriving to New Zealand would be "clean." Clean was defined as "no visible aquatic organisms, except for a slime layer" (i.e., no macrofouling) (Ministry for Primary Industries New Zealand [MPI], 2010c). The expectation was that vessels operating according to best practice would meet this standard.

At the time of consultation, MPI staff had an active role in the work conducted by the IMO, hence MPI was able to ensure alignment with both the timing and intent of IMO's biofouling guidelines (International Maritime Organization [IMO], 2011). For example, MPI's proposed regulations and measures for compliance were aligned with the pending IMO guidelines through both the information required for biofouling declarations (i.e., Biofouling Management Plans) and hull maintenance record keeping (i.e., Biofouling Record Books).

\section{Review of Submissions}

MPI received 29 written submissions during the consultation period (Ministry for Primary Industries New Zealand [MPI], 2011). The majority of submitters agreed that:

- Vessel biofouling poses a significant pathway for the introduction of NIS;

- The options considered were appropriate to protect New Zealand's values;

- A preventive strategy is appropriate;

- All vessels entering New Zealand cannot be inspected;

- Using a documentation-based system to identify risk vessels is acceptable and pragmatic (a few additional suggestions were provided); 
- The proposed phased approach to implementation was appropriate. However, the meaning of such an approach varied among stakeholders (Ministry for Primary Industries New Zealand [MPI], 2011).

Supportive submitters were, in principle, in agreement to all, or most, of MPI's proposed approach. A healthy marine environment to support commercial, recreational and cultural values was the key motivation for these stakeholders (Ministry for Primary Industries New Zealand [MPI], 2011).

Submissions opposing MPI's preferred option were concerned with potential negative flow-on effects or hindrances to tourism and trade (Ministry for Primary Industries New Zealand [MPI], 2011). These included concerns about:

- New Zealand acting unilaterally (an international solution was preferred);

- The practicality of a standard that is applicable to all vessels;

- Costs associated with compliance.

Following consultation, MPI agreed that further consideration and clarity was required regarding:

- Potential costs associated with the proposed approach;

- Definition of the clean hull standard;

- Phasing in of mandatory requirements;

- Border clearance procedures for arriving vessels (Ministry for Primary Industries New Zealand [MPI], 2011).

\section{Cost Benefit Analysis}

A cost benefit analysis (CBA) was undertaken to provide clarity regarding the consequences associated with the introduction of mandatory requirements (Branson, 2012). A range of scenarios were examined, including the influence of voluntary or mandatory adoption of biofouling management in like-minded jurisdictions (i.e., Australia and California).

The CBA found that relative to voluntary management, the benefits of the proposed mandatory measures in avoiding the impacts of NIS on affected sectors would significantly outweigh the costs within the first 10 years of implementation (Branson, 2012; Figure 2).

Over 50 years, the proposed mandatory measures were estimated to deliver additional net benefits of between \$NZD 520 million (under the scenario of mandatory requirements in Australia and California) and \$NZD 865 million (voluntary management in Australia and California). For each dollar of cost incurred, the proposed mandatory measures were estimated to deliver up to \$NZD 25 in additional benefits by this time (Branson, 2012).

\section{Science to Inform Decisions on Acceptable Levels of Biofouling}

Application of "slime layer" as the definition for a "clean hull" in MPI's proposed biofouling requirements (Ministry for Primary Industries New Zealand [MPI], 2010c) would manage the identified biosecurity risks (Bell et al., 2011), the expectation being that vessels operating according to best practice would be able to meet the standard. The intent of the IMO guidelines, an example of best practice, was to maintain the submerged surfaces and internal cooling systems of the vessels "as free of biofouling, as is practical" (International Maritime Organization [IMO], 2011). As noted in the guidelines and more recently, other than continuous grooming, no antifouling technology is currently available to prevent slime layer fouling (Dobretsov, 2010; Tribou and Swain, 2017). Further, there are instances within "normal" vessel operation that may result in macrofouling accumulation, hence, technical advice was developed to provide further clarity regarding the definition of "clean" (Georgiades and Kluza, 2014).

The thresholds of allowable fouling (i.e., fouling that does not result in an unacceptable biosecurity risk) were designed considering organism biology, MPI commissioned research (Floerl et al., 2008; Inglis et al., 2010), international research (e.g., Hilliard et al., 2006; Mineur et al., 2007, 2008; Sylvester et al., 2011), and stakeholder submissions (Ministry for Primary Industries New Zealand [MPI], 2011). To manage biosecurity risk, the thresholds were developed to limit species richness and to prevent successful reproduction and establishment of the allowed taxonomic groups, while considering the practicality and feasibility of implementation. Ultimately, these biofouling thresholds are governed by the vessel's New Zealand itinerary (Georgiades and Kluza, 2014). This technical document was externally peer reviewed by an internationally recognized subjectmatter expert, and has since been published in a peer-reviewed scientific journal (Georgiades and Kluza, 2017).

\section{THE CRAFT RISK MANAGEMENT STANDARD FOR VESSEL BIOFOULING AND ITS IMPLEMENTATION}

Following updates to the Biosecurity Act in 2012, and revisions made based on stakeholder feedback, the Craft Risk Management Standard for Biofouling on Vessels Arriving to New Zealand (CRMS-BIOFOUL) was approved on 15th May 2014 (Ministry for Primary Industries New Zealand [MPI], 2014). Implementation began with a 4-year lead-in period during which compliance was voluntary. During this period, extensive resource was focused on communicating the requirements and allowing industry time to develop and implement appropriate biofouling management practices. During this period MPI retained the power to take action on vessels that were deemed to present a severe biosecurity risk.

The CRMS-BIOFOUL requires all vessel operators to take preventive measures to manage biofouling and maintain a "clean hull" prior to arrival to New Zealand. To demonstrate compliance with the requirements, vessels must be able to present documentary evidence that one of the following measures has been undertaken:

- Continual maintenance following best practice; or

- Cleaned within 30 days prior to arrival in New Zealand; or

- Booked with an MPI-approved provider for cleaning or treatment within $24 \mathrm{~h}$ of arrival. 


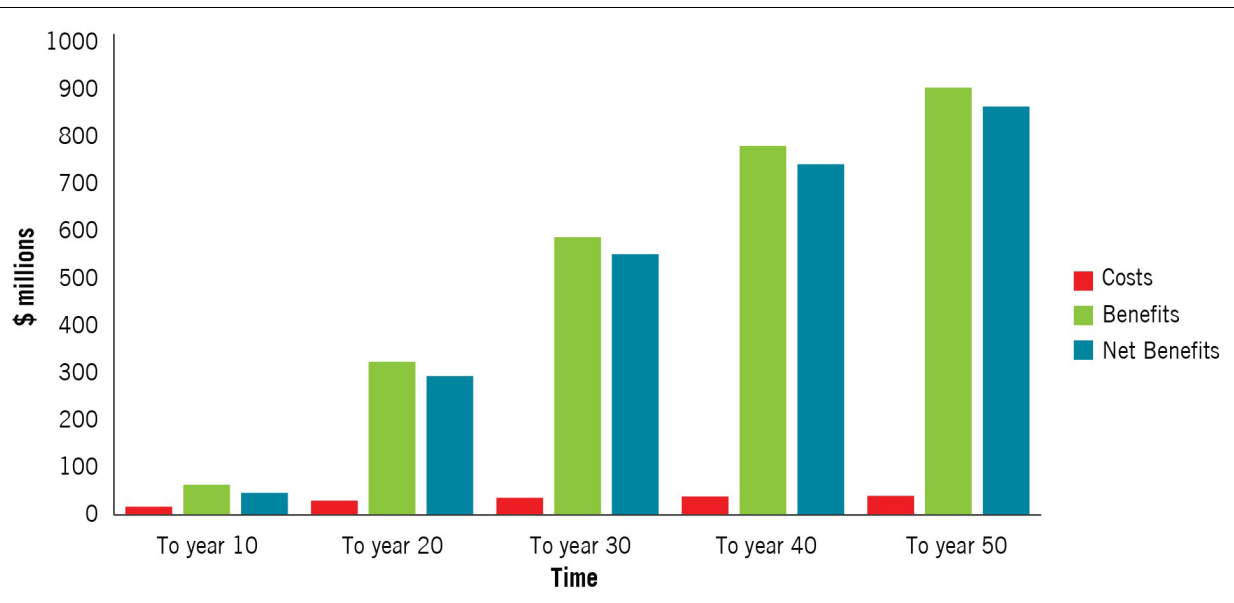

FIGURE 2 | Additional present value total costs and benefits of the proposed vessel biofouling Import Health Standard relative to voluntary standards in New Zealand, Australia, and California (Branson, 2012).

Providing multiple options to meet the standard allows vessel operators to tailor an approach to suit their operational needs. If, however, an operator cannot comply with the measures outlined above, the standard also allows operators to submit a Craft Risk Management Plan (CRMP). This must outline the risk reduction steps to be taken to achieve equivalence with the CRMS-BIOFOUL and is subject to approval.

The CRMS-BIOFOUL also defines the "clean hull" thresholds as per Georgiades and Kluza (2014). The thresholds are applied by MPI operationally if vessels are suspected to exceed the allowable limit upon receipt of initial documentation, or if a vessel fails to provide evidence that one of the above measures has been undertaken.

During the lead-in period, MPI engaged heavily with a wide variety of stakeholders in order to raise awareness of the CRMS-BIOFOUL and promote best practices for biofouling management. In addition, MPI was proactive in delivering guidance on what constitutes appropriate documentary evidence of biofouling management (e.g., input into IMarEST/IPPIC biofouling management plan template; Institute of Marine Engineering, Science and Technology/International Paint Printing Ink Council [IMAREST/IPPIC], 2016) and best practice measures (e.g., Georgiades et al., 2018).

On 15th May 2018, the requirements of the CRMS-BIOFOUL became mandatory for all vessels arriving to New Zealand. To comply, vessels must carry verifiable evidence that one of the measures outlined in the standard has been undertaken in order to meet the clean hull thresholds. Vessels that cannot demonstrate compliance are subject to increased intervention and verification. Vessels found to be fouled beyond the allowable thresholds may be subject to compliance action, such as itinerary restrictions, based on the risk posed by the fouling.

\section{ONGOING RESEARCH}

The success of any regulation, and associated best practice and risk management activities, is reliant on continuous improvement. MPI continues to invest in biofouling science and the generation of robust evidence to inform decision making. Significantly, this investment has taken a holistic approach with applicability encompassing international and national levels as well as the domestic management environment.

\section{Vessel Profiling}

The enforcement of the CRMS-BIOFOUL is dependent on MPI's ability to identify potential risk vessels. As biofouling cannot be adequately assessed during MPI's routine on-board inspections, is it imperative to have tools that allow the targeting of highrisk vessels for efficient resource allocation. MPI's commissioned research on international vessel arrivals identified a number of biofouling risk indicators, such as date of last antifouling coating application, number of port calls, and number of extended layups (Inglis et al., 2010). These indicators have been incorporated into MPI's vessel pre-arrival documentation, with the responses input into a profiling tool to assign a risk rating. MPI is actively researching the utility of the indicators through ongoing vessel surveys, with one conducted in 2016/17 (Ministry for Primary Industries New Zealand [MPI], 2015), and another which will begin in 2020 .

\section{Proactive Management}

A number of information gaps remain regarding the effectiveness of proactive measures to minimize vessel biofouling, particularly for niche areas. Therefore, MPI commissioned research to identify effective maintenance practices to inform both shipping and regulatory authorities of activities that could constitute best practice (Lewis, 2016). From this research, and a review of literature published since release of the IMO guidelines (e.g., Department of Agriculture, Fisheries and Forestry, Department of Sustainability, Environment, Water, Population and Communities, and New Zealand Ministry for Primary Industries [MPI], 2013; Institute of Marine Engineering, Science and Technology/International Paint Printing Ink Council [IMAREST/IPPIC], 2016; INTERTANKO, 2016), MPI developed 
technical advice regarding best practice biofouling management for short-stay vessels (Georgiades et al., 2018).

The following proactive management information gaps have been identified for research prioritization:

- Efficacy of fouling management within internal seawater systems (Grandison et al., 2011; Frey et al., 2014; Lewis, 2016);

- Benefits of internal seawater system management (Pamitran et al., 2016);

- Potential consequences for vessels with extended lay ups (Tribou and Swain, 2017).

\section{Reactive Management}

Risk management decisions need to balance biosecurity needs against other factors, including economics, environmental protection, practicality, and feasibility. To assist decision makers, an analysis was undertaken to understand the range of available options to manage the risk of non-compliant vessels (Inglis et al., 2012). This analysis was informed by previous MPIcommissioned research (e.g., Denny, 2007; Pannell and Coutts, 2007; Woods et al., 2007; Hopkins et al., 2008; Bohlander, 2009).

In broad terms of decreasing biosecurity risk, the range of options to manage non-compliant vessels includes:

- No action;

- Providing educational materials;

- Restricting vessel stay - single port, $>24$ h;

- Taxonomic identification of fouling;

- Restricting vessel stay - single port, $<24 \mathrm{~h}$;

- Direct vessel to a subsequent port to be cleaned or treated;

- Direct vessel to be cleaned or treated at the original recipient port;

- Haul out or dry docking;

- Refusal of entry into recipient port.

Each of the above options to manage biosecurity risk of non-compliant vessels that have entered New Zealand has associated factors that require consideration. For example, while vessels entering New Zealand are subject to various engagement strategies, and have access to information regarding biofouling management via MPI's website, supplying further materials to non-compliant vessels as a management measure in isolation only manages future risk events. Taxonomic identification is not feasible in most cases due to factors including the costs and time involved, the many areas on a vessel that are inaccessible to divers (Cahill et al., 2019a; Growcott et al., 2019), and the potential pathogens or parasites associated with the fouling organisms are unlikely to be taken into account (Howard, 1994; Deveney et al., 2017). While vessel itineraries should be restricted to be as short as possible, such a direction has flow-on effects to port logistics and vessel chartering. Haul-out and cleaning can be achieved for most recreational and fishing vessel arrivals, however this option is not available for the majority of large vessel arrivals (i.e., those vessels above 1,800 dry weight tonnage; Inglis et al., 2012).

Taking the above options into account, along with their issues of practicality and feasibility, MPI has commissioned various vessel in-water cleaning and treatment (VICT) research projects
(Morrisey and Woods, 2015; Growcott et al., 2017; Ammon et al., 2019; Cahill et al., 2019a), including those identifying the associated risks (e.g., Morrisey et al., 2013; Cahill et al., 2019b). Recently, MPI released technical advice on testing inwater cleaning and treatment systems for external hull and niche areas (Morrisey et al., 2015) and internal seawater systems (Growcott et al., 2019). Testing the practicality and feasibility of this technical advice is needed to support uptake of VICT as a biofouling management option (Scianni and Georgiades, 2019). Further commissioned research aims to help strengthen New Zealand's regulatory approach to manage VICT.

\section{DOMESTIC BIOFOULING MANAGEMENT}

Regulations to manage ballast water and biofouling pathways minimize, rather than eliminate, the likelihood of entry and establishment of NIS. Therefore robust processes are required to locate and identify new NIS to New Zealand (surveillance) and manage these incursions as appropriate (response and longterm management).

\section{Surveillance}

To determine the presence and distribution of NIS, MPI commissioned a nationwide program of baseline surveys of ports and marinas. Forty-three surveys were completed between 2001 and 2007, with 13 ports and 3 marinas subjected to repeat surveys. A total of 109 NIS were detected, 24 of which had not been previously identified in New Zealand (Seaward et al., 2015). In addition, the Marine High Risk Site Surveillance (MHRSS) program was implemented in 2002 to biannually survey 11 harbors where 7 high-risk NIS were most likely to enter and establish. The results of these programs helped to support the conclusions of the international vessel surveys (Inglis et al., 2010), i.e., the species identified on the surveyed vessels were not established in New Zealand, and the results were not an artifact of a lack of knowledge on the presence/absence of NIS.

The MHRSS program has five primary target species, which are listed on the New Zealand Unwanted Organisms Register. There are four additional secondary target organisms known to be established in New Zealand's coastal waters (Table 2). However, the techniques used to meet the objectives of the MHRSS program are non-specific, which increases the likelihood of other NIS being detected. Techniques include benthic sled tows, crab traps, and diver and shore searches which are used over a range of habitat types, such as mud and gravel bottoms, intertidal rocky shores, and artificial structures (Woods et al., 2019). Research is underway to update the MHRSS program based on the likelihood of entry of NIS through the biofouling and ballast water pathways.

\section{Response}

Despite the efforts of the MHRSS program, it is often difficult to detect the arrival of NIS early enough to enable eradication. Tools for eradicating or managing an established marine NIS are limited, difficult to perform, and expensive. For example, adjusted to 2012 prices, MPI's incursion responses to the sea squirt Styela 
TABLE 2 | Objectives and target species for MPI's MHRSS program.

\begin{tabular}{ll}
\hline Primary objective & Secondary objectives \\
\hline To detect incursions of & To detect incursions of \\
new-to-New Zealand NIS listed on the & new-to-New Zealand NIS or \\
Unwanted Organisms Register at High & cryptogenic organisms not listed on the \\
Risk Sites throughout New Zealand. & Unwanted Organisms Register at High \\
& Risk Sites throughout New Zealand. \\
& To detect incursions (i.e., range \\
& extensions) of established NIS or \\
& cryptogenic organisms that exhibit \\
characteristics of pests and diseases. \\
\hline Primary target species & Secondary target species \\
\hline Asterias amurensis & Arcuatula senhousia \\
Carcinus maenas & Eudistoma elongatum \\
Caulerpa taxifolia & Sabella spallanzanii \\
Eriocheir sinensis & Styela clava \\
Potamocorbula amurensis &
\end{tabular}

clava and the Mediterranean fanworm (Sabella spallanzanii) cost \$NZD 3 million and \$NZD 1.5 million, respectively. Between 2005 and 2010, MPI invested \$NZD 1.2 million per annum responding to $S$. clava, Didemnum vexillum, Eudistoma elongatum, S. spallanzanii, Perna perna, and Pyura doppelgangera (Branson, 2012). Only the response to P. perna resulted in eradication, however this was due to the specific nature of the event, i.e., dredging sediment following the uncontained in-water cleaning of a semi-submersible drilling rig (Hopkins et al., 2011). Much of that cost appears to have been borne by drilling rig owners (Vaughan, 2008). The eradication of the black-striped mussel (Mytilopsis sallei) from three marinas in the Northern Territory, Australia cost in excess of \$AUD 2.2 million (Willan et al., 2000; Bax et al., 2002).

Recently, MPI has responded to numerous pathogen detections, e.g., ostreid herpesvirus microvariant 1 (Keeling et al., 2014) and Bonamia ostreae (Lane, 2016). The response costs for these two pathogens have been far higher than for responses to the macrofouling organisms listed above, with the associated disease outbreaks and management decisions to prevent further spread having significant impacts on New Zealand's Pacific oyster (Magallana gigas) and flat oyster (Ostrea chilensis) industries, respectively (Castinel et al., 2015; Sim-Smith et al., 2016; Ross et al., 2017). The translocation of these pathogens has been connected to vessel biofouling (Howard, 1994; Deveney et al., 2017) and MPI has commissioned a pilot study to further investigate this transmission pathway.

\section{Long-Term Management}

Ongoing management attempts to eradicate or contain marine NIS in New Zealand have had mixed success, with results being hindered by the dispersal of the NIS either naturally or by anthropogenic means (South et al., 2017). Efforts to control and eliminate S. spallanzanii from specific locations showed that consistent management can suppress populations to very low levels (Inglis et al., 2009). Further, the Fiordland elimination program for Undaria pinnatifida had, until recently, been successful (South et al., 2017; Gnanalingam and Hepburn, 2019). Approaches that identify and manage all risk pathways would help to ensure the success of such programs (South et al., 2017).

Ongoing management can be expensive (e.g., \$NZD 2.2 million was invested in a failed attempt to eradicate $U$. pinnatifida from Big Glory Bay and Bluff; Gnanalingam and Hepburn, 2019). However, such costs need to be balanced by medium- to long-term benefits of action. For example, Hayward (1997) and Hayward et al. (1999) attributed major environmental changes in Waitemata Harbour, Auckland, to M. gigas and Arcuatula senhousia. NIS biofouling also has detrimental effects on growth and condition of cultured shellfish, as well as appearance, marketability, and production costs (Fitridge et al., 2014; Forrest et al., 2014; Davidson et al., 2017). According to Soliman and Inglis (2018), the projected impacts of S. clava and S. spallanzanii over 24 years would be approximately $4 \%$ of New Zealand's total green-lipped mussel (Perna canaliculus) industry revenue.

\section{A Domestic Pathways Approach}

The aforementioned research and lessons learned from implementation of the CRMS-BIOFOUL have been used to inform New Zealand's domestic biofouling management. Amendments to the Biosecurity Act 1993 in 2012 allowed greater scope regarding the ability to manage the domestic spread of marine NIS, e.g., the creation of pathway management plans. MPI therefore commissioned research that engaged domestic stakeholders including industry, government, tangata whenua, and regional councils, and proposed a variety of measures (Inglis et al., 2013) and policies to manage identified marine domestic risk pathways (Sinner et al., 2013).

Ministry for Primary Industries has been actively working with domestic stakeholders to raise awareness of marine biosecurity issues, and to promote consistent practice in responding to, and preventing the spread of marine NIS. MPI was part of the steering group that developed the proposal for a regional pathway management plan for the Fiordland Marine Area. The Plan was created to address risks posed by vessel biofouling, gear and equipment, and residual seawater (e.g., ballast and bilge). The biofouling requirements are consistent with the requirements for long-stay vessels within the CRMS-BIOFOUL. In 2017, the Environment Southland Council formally adopted the Fiordland Marine Pathway Management Plan, which was the first of its kind in New Zealand and a major advance for domestic marine biosecurity (Cunningham et al., 2019). The rules apply to all vessels entering within 1 nautical mile of the Fiordland Marine Area. The Northland Regional Council have since developed a pathway management plan that covers their entire jurisdiction (Northland Regional Council, 2017).

\section{ALIGNMENT OF BIOFOULING REGULATIONS}

Ministry for Primary Industries, and other like-minded jurisdictions, consider the IMO guidelines a good example of best practice principles for biofouling management, and as 
TABLE 3 | Comparison between international, national and regional biofouling requirements.

\begin{tabular}{lll}
\hline $\begin{array}{l}\text { Jurisdiction } \\
\text { (regulatory body) }\end{array}$ & Requirements & Website \\
\hline International & & \\
\hline (International & Voluntary guidelines based on minimizing fouling through ongoing maintenance using http://www.imo.org/en/OurWork/Environment/ & Biofouling/Pages/default.aspx \\
Maritime & best practice. & Details recorded in a biofouling management plan and record book. \\
Organization) & Not mandatory.
\end{tabular}

\section{National}

New Zealand

(Ministry for Primary

Industries)
Vessels to arrive in New Zealand with a "clean" hull.

Clean has defined thresholds based on vessel itinerary.

Standard can be met with evidence of ongoing maintenance using best practice. An up to date biofouling management plan and record book as per IMO is an example of this. Applies to all vessel types.

\section{Australia}

(Department of

Agriculture, Water

and the Environment)
IMO-consistent mandatory biofouling management standards for vessels entering Australian Territorial seas (12 NM) undergoing development. https://www.mpi.govt.nz/importing/borderclearance/vessels/arrival-process-steps/biofouling/ biofouling-management/

https://www.agriculture.gov.au/biosecurity/avm/ vessels/marine-pest-biosecurity/biofouling
United States

(Environmental

Protection Agency)
Vessel owners must minimize the transport of attached living organisms when traveling into US waters from outside the US Exclusive Economic Zone or between Captain of the Port zones.

The includes:

Conduct of comprehensive annual inspections of the vessel hull, including niche areas for fouling organisms, flaking paint, etc.

Preparation of dry-dock inspection reports noting, among other things - proper cleaning of the chain locker, and inspection and cleaning of vessel hull and niche areas. When feasible, flush-fitting of sacrificial anodes to the hull, or the filling of any space between the anode and the hull to remove the potential for hotspots for biofouling organisms.

Removal of biofouling organisms from seawater piping on a regular basis and dispose of removed substances in accordance with local, state, and federal regulations. All in-water biofouling removal activities to minimize the discharge of biofouling organisms and antifouling coatings.

These are consistent with management principles established in the IMO guidelines, but not currently an enforcement priority.

The Vessel Incidental Discharge Act (VIDA) was signed into law in late 2018 (anticipated to come into force in 2022). VIDA requires EPA to develop new national performance standards for incidental discharges from commercial vessel. The US Coast Guard is required to develop corresponding implementing regulations.

The above regulations are primarily directed at commercial vessels.

The Uniform National Discharge Standards regulate military vessels.

Development of standards for recreational vessels is under the Clean Boating Act.

United States

(US Coast Guard)
Remove fouling organisms from the vessel's hull, piping, and tanks on a regular basis and dispose of any removed substances in accordance with local, state, and federal regulations.

Rinse anchors and anchor chains when the anchor is retrieved to remove organisms and sediments at their places of origin.

Carrying a Biofouling Management Plan in accordance with the IMO guidelines is one way of fulfilling the requirements.
https://www.dco.uscg.mil/Our-

Organization/Assistant-Commandant-forPrevention-Policy-CG-5P/Commercial-Regulationsstandards-CG-5PS/Office-of-Operating-andEnvironmental-Standards/EnvironmentalStandards/BW-Regs-and-

Policy/https://www.dco.uscg.mil/OurOrganization/Assistant-Commandant-forPrevention-Policy-CG-5P/Commercial-Regulationsstandards-CG-5PS/Office-of-Operating-andEnvironmental-Standards/EnvironmentalStandards/BW-Regs-and-Policy/

\section{Regional (New Zealand)}

(Department of Vessels intending to go inside 1,000 $\mathrm{m}$ from mean high water springs of the Kermadec Conservation) and Subantarctic islands required to have a clean hull.

Clean hull definitions based on those defined in CRMS-BIOFOUL.

Vessels must have an up to date biofouling management plan and record book.

Inspection requirements included.

Applies to Kermadec and Subantarctic Islands only. https://www.doc.govt.nz/globalassets/documents/ about-doc/conservation-management/coastalmanagement/regional-coastal-plan-kermadecssubantarctics.pdf https://www.epa.gov/npdes/vessels-vgp https://www.epa.gov/vessels-marinas-and-ports/ uniform-national-discharge-standards-undshttps://www.epa.gov/vessels-marinas-and-ports/ https://www.congress.gov/115/bills/s140/BILLS115s140enr.pdf 
TABLE 3 | Continued

\begin{tabular}{ll}
\hline $\begin{array}{l}\text { Jurisdiction } \\
\text { (regulatory body) }\end{array}$ & Requirements \\
\hline (Northland Regional Council) & Vessels should have no more than a "light fouling" upon entering \\
& Northland or moving to another 'designated place' in Northland- $\quad$ https://www.nrc.govt.nz/environment/weed-and- \\
& that is, another harbor or popular offshore anchorage. $\quad$ pathway-rules-for-northland/ \\
& "Light fouling" means no more than small patches (up to $100 \mathrm{~mm}$ in \\
& diameter) of visible fouling, totaling less than $5 \%$ of the hull and \\
& niche areas. A slime layer and/or barnacles are acceptable.
\end{tabular}
\begin{tabular}{ll}
\hline (Environment Southland) & All vessels must hold a Clean Vessel Pass. \\
& The hull and niche areas have no more than a slime layer and goose \\
& barnacles.
\end{tabular} https://www.es.govt.nz/environment/biosecurityand-biodiversity/marine-biosecurity/fiordlandOnly applies to vessels entering within 1 nautical mile of the marine-pathway-plan Fiordland Marine Area.

\section{Regional (International)}

Western Australia and Regional Development)
[Australia]

(Department of Primary Industries
Under the Fisheries Resource Management Act vessels must not bring in any non-endemic fish (which includes fish, invertebrates, algae, etc.).

Vessels associated with resource or development projects may have extra prescribed Ministerial conditions which vary according to the risk posed. These may include compulsory risk assessment, inspections and proof of 'pest free' status.

Future management will require vessels to be subject to a Departmentally approved risk assessment (Vessel Check) process and provide evidence of up to date biofouling management plans and record books (consistent with IMO guidelines).
http://www.fish.wa.gov.au/Sustainability-andEnvironment/Aquatic-Biosecurity/Vessels-AndPorts/Pages/Legislation-Policies-And-Advice.aspx http://www.fish.wa.gov.au/Sustainability-andEnvironment/Aquatic-Biosecurity/Nessels-AndPorts/Pages/Biofouling-management-tools-andguidelines.aspx https://www.vessel-check.com/auth/home-page
Northern Territory

[Australia]

(Northern Territory Department of

Primary Industry and Resources)

California [United States]

(California State Lands

Commission)
Recreational vessels must arrive "clean" and will be subject to inspection.

Applies to recreational vessels only. https://nt.gov.au/marine/for-all-harbour-and-boatusers/biosecurity/hull-pest-inspections-for-visitingboats
Annual submission of Annual Vessel Reporting Form.

Able to provide an up to date biofouling management plan and record book (largely in line with IMO guidelines), including mandatory management of specific niche areas (additional to IMO guidelines).

Applies to vessels capable of carrying ballast $\geq 300$ gross registered tons.
Papahanaumokuakea Marine

National Monument

Maintain all submerged and waterline surfaces free of macrofouling.
https://govt.westlaw.com/calregs/Browse/Home/ California/CaliforniaCodeofRegulations?guid= I7B8BB9028E8D46DFB63FBC7410E45356\& originationContext=documenttoc\&transitionType= Default\&contextData=(sc.Default)
[United States]

[Department of Commerce

(National Oceanic and Atmospheric

Administration)

Secretary of the Interior

(United States Fish and Wildlife

Service)

State of Hawaii (Department of

Land and Natural Resources)]

\section{Galapagos Marine Reserve}

[Ecuador]

(Agencia de Regulación y Control

de la Bioseguridad y Cuarentena

para Galápagos - ABG)
Arriving vessels from mainland Guayaquil subject to hull inspections. Arriving international vessels must present ABG with a checklist which includes a hull cleaning certificate. The clean must take place 2 days prior to departure. Vessels will still be subject to hull inspection upon arrival. such, MPI incorporated these guidelines by reference into the CRMS-BIOFOUL (Table 3). While regulations vary among jurisdictions due to their different legislative frameworks, it is notable that many are aligned and consistent with voluntary IMO guidelines, e.g., California's regulations, United States federal regulations (undergoing review), and Australia's proposed regulations (Table 3).

New Zealand's biofouling regulations differ from those of other jurisdictions as they are set at a national level and manage the risks associated with all vessel types. Other regulations s://bioseguridadgalapagos.gob.ec/ http://extwprlegs1.fao.org/docs/pdf/ecu168982.pdf (Spanish) bestmanagement.html 
are either set at a regional level or only manage a specific vessel class (Table 3). Notably, the science underpinning, and thresholds within, the CRMS-BIOFOUL has informed New Zealand domestic regulations and practices (Table 3).

\section{EFFECTIVENESS}

As the CRMS-BIOFOUL requirements only became mandatory in 2018, to categorically state their effectiveness in minimizing the introduction of NIS is premature. Based on the current profiling and resourcing, early indications are cautiously optimistic, with $<2 \%$ of commercial vessels being issued Notices of Direction for non-compliance up to April 2020.

Data regarding the cleanliness of vessels arriving into New Zealand provides early indications of a lessening of propagule pressure (Lockwood and Cassey, 2005). For example, New Zealand annually receives $>650$ international recreational vessel arrivals (Inglis et al., 2012). Research showed that a large proportion $(>80 \%)$ of these vessels carry fouling assemblages on their hulls which, in most cases, included NIS (Floerl et al., 2008). Since implementation, only three recreational vessels have required border intervention, noting that these vessels often have to meet the cleanliness threshold for long-stay vessels (MPI internal data).

Domestically, there are anecdotal reports that vessels arriving from regions with biofouling regulations are often cleaner than those without (MPI unpublished data). However, it is difficult to determine the effectiveness of these early regulations, as biofouling is not the only pathway for the domestic spread of NIS (e.g., ballast water, aquaculture stock and equipment), and marine NIS surveillance is continually improving (Zaiko et al., 2018).

\section{CONCLUSION}

Globally, regulators face similar issues regarding the development and implementation of options and guidance to manage the risks associated with vessel biofouling. New Zealand was the first country to institute a standard for biofouling that applies

\section{REFERENCES}

Allen, F. E. (1953). Distribution of marine invertebrates by ships. Aust. J. Mar. Freshwat. Res. 1, 106-109.

Allen, W., Elmetri, I., Clarke, S., Gibbons, J., Clark, K., Sinner, J., et al. (2009). Mapping the Values of New Zealand's Coastal Waters: 3. Social Values. Biosecurity New Zealand Technical Paper No. 2010/05. Wellington: Ministry of Agriculture and Forestry.

Ammon, U., Swift, L., Brand, S., Jeffs, A., and Swift, S. (2019). Review of In-Water Hull Encapsulation and Enclosure Treatments for Eliminating Marine Biofouling. Technical Paper No. 2019/06. Wellington: Ministry for Primary Industries.

Anderson, C., Atlar, M., Callow, M., Candries, M., Milne, A., and Townsin, R. L. (2003). The development of foul-release coatings for seagoing vessels. Proc. IMarEst B J. Mar. Design Operat. 4, 11-23.

Bax, N., Hayes, K., Marshall, A., Parry, D., and Thresher, R. (2002). "Man-made marinas as sheltered islands for alien marine organisms: establishment and eradication of an alien invasive marine species," in Turning the Tide: The Eradication of Invasive Species, eds C. R. Veitch, and M. N. Clout (Switzerland: to all international vessel arrivals. The effectiveness of this ground-breaking standard is reliant on international promotion of the regulations, management measures, and the key roles of the science, research, and risk assessment to underpin them. The formation of aligned regulation in other jurisdictions, and industries within them, is crucial to success as aligned regulation will ensure better uptake to protect global and local (New Zealand) marine values. Hence, as an early-adopter of mandatory biofouling regulations, MPI's experience provides an evidence base and a blueprint for their establishment. Because these are aligned with the IMO guidelines, there is the potential to develop consistent global and domestic practices for managing marine NIS introduction and spread.

\section{AUTHOR CONTRIBUTIONS}

All authors listed have made a substantial, direct and intellectual contribution to the work, and approved it for publication.

\section{FUNDING}

This review paper was supported by New Zealand Government (Biosecurity Science and Risk Assessment Directorate, Ministry for Primary Industries).

\section{ACKNOWLEDGMENTS}

The authors wish to thank past and present members of MPI, our national and international counterparts, and our service providers who have worked in progressing New Zealand's marine biosecurity system. S. Leelawardana, C. Reed, and E. Perotti (MPI) reviewed draft versions of the manuscript. Funding and support from MPI's Operational Research Team is gratefully acknowledged. The Marine Biosecurity Regulatory Agency Informal Network assisted with collation of Table 3. The reviewers' feedback greatly improved this manuscript.

International Union for Conservation of Nature Invasive Species Specialist Group), 26-39.

Beaumont, J., Oliver, M., and MacDiarmid, A. (2008). Mapping the Values of New Zealand's Coastal Waters. 1: Environmental Values. Ministry of Agriculture and Forestry Biosecurity New Zealand Technical Paper No. 2008/16. Wellington: Ministry of Agriculture and Forestry Biosecurity New Zealand.

Bell, A., Phillips, S., Denny, C., Georgiades, E., and Kluza, D. (2011). Risk Analysis: Vessel Biofouling. Wellington: Ministry of Agriculture and Forestry Biosecurity New Zealand.

Bohlander, J. (2009). Review of Options for in-Water Cleaning of Ships. Ministry of Agriculture and Forestry Biosecurity New Zealand Technical Paper No. 2009/42. Wellington: Ministry of Agriculture and Forestry Biosecurity New Zealand.

Branson, J. (2012). Cost-Benefit Analysis of Proposed Import Health Standard for Vessel Biofouling. Ministry for Primary Industries Technical Paper No. 2018/68. Wellington: Ministry for Primary Industries.

Cahill, P., Hickey, C., Lewis, P., Tait, L., and Floerl, O. (2019a). Treatment Agents for Biofouling in Internal Pipework of Recreational Vessels. Ministry for Primary 
Industries Technical Paper No. 2019/03. Wellington: Ministry for Primary Industries.

Cahill, P., Tait, L., Floerl, O., Bates, T., Growcott, A., and Georgiades, E. (2019b). Design and assessment of a thermal treatment system for fouled internal pipework of recreational vessels. Mar. Pollut. Bull. 139, 65-73. doi: 10.1016/ j.marpolbul.2018.12.032

Carlton, J. T., and Geller, J. B. (1993). Ecological roulette: the global transport and invasion of non-indigenous marine organisms. Science 261, 78-82. doi: $10.1126 /$ science.261.5117.78

Carlton, J. T., Keith, I., and Ruiz, G. M. (2019). Assessing marine bioinvasions in the Galápagos Islands: implications for conservation biology and marine protected areas. Aquat. Invasions 14, 1-20. doi: 10.3391/ai.2019.14.1.01

Carlton, J. T., Reid, D. M., and van Leeuwen, H. (1995). Shipping Study - The Role of Shipping in the Introduction of Non-Indigenous Aquatic Organisms to the Coastal Waters of the United States (Other Than the Great Lakes) and An Analysis of Control Options. The National Sea Grant Program/Connecticut Sea Grant Project R/ES-6 No. CG-D-11-95.

Castinel, A., Fletcher, L., Dhand, N., Rubio, A., Whittington, R., and Taylor, M. (2015). OsHV-1 Mortalities in Pacific Oysters in Australia and New Zealand: the Farmer's Story. Cawthron Report No. 2567. Wellington: Ministry of Business, Innovation and Employment.

Cawthron Institute, (2010). Vessel Biofouling as a Vector for the Introduction of Non-Indigenous Marine Species to New Zealand: Slow-Moving Barges and Oil Platforms. Ministry for Agriculture and Forestry Biosecurity New Zealand Technical Paper No. 2010/12. Biosecurity New Zealand Project ZBS2005-02. Wellington: Ministry for Agriculture and Forestry Biosecurity New Zealand.

Chilton, C. (1910). Dispersal of marine crustacea by means of ships. Trans. New Zeal. Inst. 43, 131-133.

Costello, M. J., Coll, M., Danovaro, R., Halpin, P., Ojaveer, H., and Miloslavich, P. (2010). A census of marine biodiversity knowledge, resources, and future challenges. PLoS One 5:e12110. doi: 10.1371/journal.pone.0012110

Cranfield, H. J., Gordon, D. P., Willan, R. C., Marshall, B. A., Battershill, C. N., Francis, M. P., et al. (1998). Adventive Marine Species in New Zealand. NIWA Technical Report 34. Wellington: Ministry for Primary Industries.

Crooks, J. A., Chang, A. L., and Ruiz, G. M. (2011). Aquatic pollution increases the relative success of invasive species. Biol. Invasions 13, 165-176. doi: 10.1007/ s10530-010-9799-3

Cunningham, S., Teirney, L., Brunton, J., McLeod, R., Bowman, R., Richards, D., et al. (2019). Mitigating the threat of invasive marine species to Fiordland: New Zealand's first pathway management plan. Manag. Biol. Invasion. 10, 690-708. doi: 10.3391/mbi.2019.10.4.07

Davidson, J. D. P., Landry, T., Johnson, G. R., and Quijón, P. A. (2017). A cost-benefit analysis of four treatment regimes for the invasive tunicate Ciona intestinalis on mussel farms. Manag. Biol. Invasion. 8, 163-170. doi: 10.3391/ mbi.2017.8.2.04

Denny, C. M. (2007). In Situ Plastic Encapsulation of the NZHMS Canterbury Frigate: A Trial of a Response Tool for Marine Fouling Pests. Cawthron Report No. 1271. Prepared for Ministry of Agriculture Biosecurity New Zealand. Wellington: Ministry of Agriculture Biosecurity New Zealand.

Department of Agriculture, Fisheries and Forestry, Department of Sustainability, Environment, Water, Population and Communities, and New Zealand Ministry for Primary Industries [MPI] (2013). Anti-Fouling and In-Water Cleaning Guidelines. Canberra: Department of Agriculture, Fisheries and Forestry.

Deveney, M., Roberts, S., Moody, N., Crane, M., and Ellard, K. (2017). "Biofouling as a long distance vector for pathogens," in Proceedings of the 4th FRDC Australasian Aquatic Animal Health and Biosecurity Scientific Conference, ed. M. S. J. Crane (Canberra: Fisheries Research and Development Corporation).

Dobretsov, S. (2010). "Marine biofilms," in Biofouling, eds S. Dürr, and J. C. Thomasson (Oxford, UK: Wiley-Blackwell), 123-136. doi: 10.1002/ 9781444315462.ch9

Eldredge, L. G., and Carlton, J. T. (2002). Hawai'ian marine bioinvasions: a preliminary assessment. Pac. Sci. 56, 211-212. doi: 10.1353/psc.2002.0012

Ferrario, J., Caronni, S., Occhipinti-Ambrogi, A., and Marchini, A. (2017). Role of commercial harbours and recreational marinas in the spread of non-indigenous fouling species. Biofouling 33, 651-660. doi: 10.1080/08927014.2017.1351958

Fitridge, I., Sievers, M., Dempster, T., and Keough, M. J. (2014). Tackling a Critical Industry Bottleneck: Developing Methods to Avoid, Prevent and Treat Biofouling in Mussel Farms. Melbourne: University of Melbourne.
Floerl, O., Inglis, G. J., Dey, K., and Smith, A. (2009). The importance of transport hubs in stepping-stone invasions. J. Appl. Ecol. 46, 37-45. doi: 10.1111/j.13652664.2008.01540.x

Floerl, O., Smith, M., Inglis, G., Davey, N., Seaward, K., Johnston, O., et al. (2008). Vessel Biofouling as a Vector for the Introduction of Non-Indigenous Marine Species to New Zealand: Recreational Yachts. Research Project No. ZBS2004-03A. Wellington: Ministry of Agriculture Biosecurity New Zealand.

Fofonoff, P. W., Ruiz, G. M., Steves, B., and Carlton, J. T. (2003). "In ships or on ships? Mechanisms of transfer and invasion for non-native species to the coasts of North America," in Invasive Species: Vectors and Management Strategies, eds G. M. Ruiz, and J. T. Carlton (Washington: Island Press), 152-182.

Food and Agriculture Organization of the United Nations [FAO] (2007). FAO Biosecurity Toolkit - General Principles of Risk Analysis. Rome: Food and Agriculture Organization.

Food and Agriculture Organization of the United Nations [FAO] (2018). The State of World Fisheries and Aquaculture 2018 - Meeting the Sustainable Development Goals. Rome: Food and Agriculture Organization.

Forrest, B., Cahill, P., Newcombe, E., and Taylor, D. (2014). Marine Pests and Management Concepts for Shellfish Aquaculture. Nelson: Cawthron Institute.

Frey, M. A., Simard, N., Robichaud, D. D., Martin, J. L., and Therriault, T. W. (2014). Fouling around: vessel sea-chests as a vector for the introduction and spread of aquatic invasive species. Manag. Biol. Invasion. 5, 21-30. doi: 10.3391/ mbi.2014.5.1.02

Georgiades, E., Growcott, A., and Kluza, D. (2018). Technical Guidance on Biofouling Management for Vessels Arriving to New Zealand. Ministry for Primary Industries Technical Paper No. 2018/07. Wellington: Ministry for Primary Industries.

Georgiades, E., and Kluza, D. (2014). Science Underpinning the Thresholds Proposed in the CRMS: Biofouling on Vessels Arriving to New Zealand. New Zealand Ministry for Primary Industries Technical Paper No. 2014/22. Wellington: Ministry for Primary Industries.

Georgiades, E., and Kluza, D. (2017). Evidence-based decision making to underpin the thresholds in New Zealand's CRMS: biofouling on vessels arriving to New Zealand. J. Mar. Sci. Technol. 51, 76-88. doi: $10.4031 / \mathrm{mtsj} .51 .2 .5$

Gnanalingam, G., and Hepburn, C. D. (2019). Control of Undaria pinnatifida in Breaksea Sound, Fiordland. Invercargill: Environment Southland.

Gollasch, S., MacDonald, E., Belson, S., Botnen, H., Christensen, J. T., Hamer, J. P., et al. (2002). "Life in ballast tanks," in Aquatic Invasive Species of Europe Distribution, Impacts and Management, eds E. Leppäkoski, S. Gollasch, and S. Olenin (London: Kluwer Academic Publishers), 217-231.

Grandison, C., Piola, R., and Fletcher, L. (2011). A Review of Marine Growth Protection System (MGPS) Options for the Royal Australian Navy. DSTO-TR2631. Fairbairn: Defence Science and Technology Organisation.

Growcott, A., Kluza, D., and Georgiades, E. (2017). Review: in-water systems to reactively manage biofouling in sea chests and internal pipework. J. Mar. Sci. Technol. 51, 89-104. doi: 10.4031/mtsj.51.2.3

Growcott, A., Kluza, D., and Georgiades, E. (2019). Technical Advice: Evaluation of in-Water Systems to Reactively Treat or Remove Biofouling within Vessel Internal Niche Areas. New Zealand Ministry for Primary Industries Technical Paper No. 2019/02. Wellington: Ministry for Primary Industries.

Hayward, B. W. (1997). Introduced marine organisms in New Zealand and their impact in the Waitemata Harbour, Auckland. Tane 36, 197-223.

Hayward, B. W., Morley, M. S., Stephenson, A. B., Blom, W. M., Grenfell, H. R., Prasad, R., et al. (1999). Intertidal and Subtidal Biota and Habitats of the Central Waitemata Harbour. Technical Publication 127. Auckland: Auckland Regional Council.

Hewitt, C. L., Campbell, M. L., Thresher, R. E., Martin, R. B., Boyd, S., Cohen, B. F., et al. (2004). Introduced and cryptogenic species in Port Phillip Bay, Victoria, Australia. Mar. Biol. 144, 183-202. doi: 10.1007/s00227-003$1173-\mathrm{x}$

Hilliard, R., Polglaze, J., and Le Provost, I. (2006). Review and Evaluation of the Biofouling Protocol for Vessels less than $25 \mathrm{~m}$ in Length. Canberra: Australian Quarantine and Inspection Service.

Hopkins, G., Forrest, B., and Coutts, A. (2008). Determining the Efficiency of Incursion Response Tools - Rotating Brush Technology (Coupled With Suction Capability). Biosecurity New Zealand Technical Paper No. 2009/39. Wellington: Ministry of Agriculture Biosecurity New Zealand Biosecurity New Zealand. 
Hopkins, G. A., Forrest, B. M., Jiang, W., and Gardner, J. P. A. (2011). Successful eradication of a non-indigenous marine bivalve from a subtidal soft sediment environment. J. Appl. Ecol. 48, 424-431. doi: 10.1111/j.1365-2664.2010.01941.x

Howard, A. E. (1994). The possibility of long distance transmission of Bonamia by fouling on boat hulls. B. Eur. Assoc. Fish Path. 14, 211-212.

Inglis, G. (2001). Criteria for Selecting New Zealand Ports and Other Points of Entry that Have a High Risk of Invasion by New Exotic Marine Organisms. Final research report for Ministry of Fisheries, research project ZBS2000/01A, objectives 1 and 2. Wellington: Ministry of Fisheries.

Inglis, G. J., Floerl, O., Ahyong, S., Cox, S., Unwin, M., Ponder-Sutton, A., et al. (2010). The Biosecurity Risks Associated with Biofouling on International Vessels Arriving in New Zealand: Summary of the Patterns and Predictors of Fouling. A Report Prepared for Ministry of Agriculture Biosecurity New Zealand Biosecurity New Zealand. Wellington: Ministry of Agriculture Biosecurity New Zealand.

Inglis, G. J., Floerl, O., Seaward, K., Woods, C., Read, G., and Peacock, L. (2009). Sabella Local Elimination Programme - Phase 1. A report prepared for Ministry of Agriculture Biosecurity New Zealand Biosecurity New Zealand. Wellington: Ministry of Agriculture Biosecurity New Zealand.

Inglis, G. J., Floerl, O., and Woods, C. (2012). Scenarios of Vessel Biofouling Risk and Their Management: An Evaluation of Options. Technical Paper No. 2012/07. Wellington: Ministry of Agriculture and Forestry.

Inglis, G. J., Morrisey, D., Woods, C., Sinner, J., and Newton, M. (2013). Managing the Domestic Spread of Harmful Marine Organisms. Part A: Operational Tools for Management. Wellington: Ministry for Primary Industries.

Institute of Marine Engineering, Science and Technology/International Paint and Printing Ink Council [IMAREST/IPPIC] (2016). A Template for Completion of a Biofouling Management Plan. Agenda: International Maritime Organization, Marine Environmental Protection Committee.

International Maritime Organization [IMO] (2004). International Convention for the Control and Management of Ships' Ballast Water and Sediments. London: International Maritime Organization.

International Maritime Organization [IMO] (2011). Guidelines for the Control and Management of Ships' Biofouling to Minimize the Transfer Of Invasive Aquatic Species. London: International Maritime Organization.

International Maritime Organization [IMO] (2017a). IMO Frequently Asked Questions Implementing the Ballast Water Management Convention. London: International Maritime Organization.

International Maritime Organization [IMO] (2017b). International Convention for the Control and Management of Ships'Ballast Water and Sediments (BWM). London: International Maritime Organization.

International Maritime Organization [IMO] (2017c). New Global Project to Address Bioinvasions via Ship's Hulls. London: International Maritime Organization.

INTERTANKO, (2016). INTERTANKO Guide to Modern Antifouling Systems and Biofouling Management. Oslo: INTERTANKO.

James, P., and Hayden, B. (2000). The Potential for the Introduction of Exotic Species by Vessel Hull Fouling: A Preliminary Study. NIWA client report WLG00/51 No. 16. Wellington: NIWA.

Keeling, S. E., Brosnahan, C. L., Williams, R., Gias, E., Hannah, M., Bueno, R., et al. (2014). New Zealand juvenile oyster mortality associated with ostreid herpesvirus 1 - an opportunistic longitudinal study. Dis. Aquat. Org. 109, 231-239. doi: 10.3354/dao02735

Kospartov, M., Inglis, G., Seaward, K., van den Brink, A., D’ Archino, R., and Ahyong, S. (2008). Nonindigenous and Cryptogenic Marine Species in New Zealand - Current State of Knowledge. NIWA Research Report Prepared for MAF-BNZ Project BNZ10740. Wellington: NIWA.

Lane, H. S. (2016). Bonamia ostreae in the New Zealand oyster Ostrea chilensis: a new host and geographic record for this haplosporidian parasite. Dis. Aquat. Org. 118, 55-63. doi: 10.3354/dao02960

Lewis, J. (2016). Assessment of Preventative Biofouling Management Measures. New Zealand Ministry for Primary Industries Technical Paper No. 2016/69. Wellington: Ministry for Primary Industries.

Lewis, J. A. (2004). Hull Fouling as a Vector for the Translocation of Marine Organisms: Report 1: Hull Fouling Research. Ballast Water Research Series Report No. 14. Canberra: Department of Agriculture, Fisheries and Forestry.
Lockwood, J., and Cassey, P. B. T. (2005). The role of propagule pressure in explaining species invasions. Trends Ecol. Evol. 20, 223-228. doi: 10.1016/j.tree. 2005.02.004

Maritime New Zealand, (2018). Marine Protection Rules. Part 300: Ballast. MNZ Consolidation 27 July 2018. Wellington: Maritime New Zealand.

McKenzie, L. A., Brooks, R. C., and Johnston, E. L. (2012). A widespread contaminant enhances invasion success of a marine invader. J. Appl. Ecol. 49, 767-773. doi: 10.1111/j.1365-2664.2012.02158.x

Minchin, D., Floerl, O., Savini, D., and Occhipinti-Ambrogi, A. (2006). "Small craft and the spread of exotic species," in The Ecology of Transportation: Managing Mobility for the Environment, eds J. Davenport, and J. L. Davenport, (Cham: Springer), 99-118. doi: 10.1007/1-4020-4504-2_6

Mineur, F., Johnson, M. P., and Maggs, C. A. (2008). Macroalgal introductions by hull fouling on recreational vessels: seaweeds and sailors. Environ. Manag. 42, 667-676. doi: 10.1007/s00267-008-9185-4

Mineur, F., Johnson, M. P., Maggs, C. A., and Stegenga, H. (2007). Hull fouling on commercial ships as a vector of macroalgal introduction. Mar. Biol. 151, 1299-1307. doi: 10.1007/s00227-006-0567-y

Ministry for Primary Industries New Zealand [MPI] (2005). Import Health Standards for Ships' Ballast Water from All Countries. Issued Pursuant to Section 22 of the Biosecurity Act 1993. Dated 13 June 2005. Wellington: Ministry of Agriculture and Forestry Biosecurity New Zealand.

Ministry for Primary Industries New Zealand [MPI] (2006). Risk Analysis Procedures. Version 1, 12 April 2006. Wellington: Ministry of Agriculture and Forestry Biosecurity New Zealand.

Ministry for Primary Industries New Zealand [MPI] (2010a). Draft Guidance Document in Support of the Import Health Standard for Vessel Biofouling. Wellington: Ministry of Agriculture and Forestry Biosecurity New Zealand.

Ministry for Primary Industries New Zealand [MPI] (2010b). Draft Requirements for Approval as a Decontamination Facility for Vessel Biofouling. Wellington: Ministry of Agriculture and Forestry Biosecurity New Zealand.

Ministry for Primary Industries New Zealand [MPI] (2010c). Import Health Standard for Vessel Biofouling. Draft for Consultation. Wellington: Ministry of Agriculture and Forestry Biosecurity New Zealand.

Ministry for Primary Industries New Zealand [MPI] (2010d). Managing and Controlling the Risk Posed to the Marine Environment from Biofouling on Arriving Vessels. Ministry of Agriculture and Forestry Biosecurity New Zealand Consultation Paper No. 10/04. Wellington: Ministry of Agriculture and Forestry Biosecurity New Zealand.

Ministry for Primary Industries New Zealand [MPI] (2011). Import Health Standard: Vessel Biofouling. Review of Submissions. Wellington: Ministry of Agriculture and Forestry Biosecurity New Zealand.

Ministry for Primary Industries New Zealand [MPI] (2014). Craft Risk Management Standard: Biofouling on Vessels Arriving to New Zealand. CRMS - BIOFOUL. Wellington: Ministry for Primary Industries.

Ministry for Primary Industries New Zealand [MPI] (2015). Request for Proposal - 404877 Vessel Biofouling Risk Profiling. Wellington: Ministry for Primary Industries.

Ministry for Primary Industries New Zealand [MPI] (2019). Situation and outlook for primary industries, June 2019. Wellington: Ministry for Primary Industries.

Minton, M. S., Verling, E., Miller, A. W., and Ruiz, G. M. (2005). Reducing propagule supply and coastal invasions via ships: effects of emerging strategies. Front. Ecol. Environ. 3, 304-308. doi: 10.1890/1540-92952005003[0304: RPSACI]2.0.CO;2

Moon, P. (2015). Discovery myths of New Zealand: some cultural, historical, and philosophical perspectives. Te Kaharoa 8, 1-44.

Morgan, T. K. K. B. (2006). An indigenous perspective on water recycling. Desalination 187, 127-136. doi: 10.1016/j.desal.2005.04.073

Morrisey, D., Gadd, J., Page, M., Lewis, J., Bell, A., and Georgiades, E. (2013). In-Water Cleaning Of Vessels: Biosecurity and Chemical Contamination Risks. New Zealand Ministry for Primary Industries Technical Paper No. 2013/11. Wellington: Ministry for Primary Industries.

Morrisey, D., Inglis, G., Tait, L., Woods, C., Lewis, J., and Georgiades, E. (2015). Procedures for Evaluating In-Water Systems to Remove or Treat Vessel Biofouling. New Zealand Ministry for Primary Industries Technical Paper No. 2015/39. Wellington: Ministry for Primary Industries. 
Morrisey, D., and Woods, C. (2015). In-Water Cleaning Technologies: Review of Information. New Zealand Ministry for Primary Industries Technical Paper No. 2015/38. Wellington: Ministry for Primary Industries.

New Zealand Customs Service [NZCS] (2008). International Vessel Arrival and Departure Information 2000 - 2007. Supplied by the Intelligence Section of the New Zealand Customs Service in March 2008. Wellington: New Zealand Customs Service.

New Zealand Customs Service [NZCS] (2010). Annual Report 2009/10. Wellington: New Zealand Customs Service.

New Zealand Government, (2000). New Zealand Biodiversity Strategy. Wellington: Department of Conservation.

New Zealand Government, (2019). Aquaculture Strategy. Wellington: New Zealand Government.

New Zealand Parliament, (1993). Biosecurity Act 1993. Public Act 1993 No. 95. Date of A assent: 26 August 1993. Wellington: New Zealand Parliament.

New Zealand Parliament, (1994). Maritime Transport Act 1994. Public Act 1994 No. 104. Date of Assent: 17 November 1994. Reprinted on 1 January 2020. Wellington: New Zealand Parliament.

Northland Regional Council, (2017). Northland Regional Pest and Marine Pathway Management Plan 2017-2019. Whangārei: Northland Regional Council.

Otani, M. (2006). "Important vectors for marine organisms unintentionally introduced to Japanese waters," in Assessment and Control of Biological Invasion Risks, eds F. Koike, M. N. Clout, M. Kawamichi, M. De Poorter, and K. Iwatsuki, (Switzerland: International Union for Conservation of Nature), 92-103.

Pamitran, A. S., Adam, S. A., and Alhamid, M. I. (2016). Cost estimation study for the effect of biofouling on engine cooling system performance with an 8000 BHP vessel. Appl. Mech. Mater. 819, 427-431. doi: 10.4028/www.scientific.net/ amm.819.427

Pannell, A., and Coutts, A. D. M. (2007). Marine Pest Control Tools. Treatment Methods Used by Industry to Manage Didemnum vexillum in the Top of the South Island. Project 764003. Biosecurity New Zealand Report prepared by the Marine Farming Association, Final draft. Wellington: Biosecurity New Zealand.

Piola, R., and Conwell, C. (2010). Vessel Biofouling as a Vector for the Introduction of Non-Indigenous Marine Species to New Zealand: Fishing Vessels. MAF Biosecurity New Zealand Technical Paper No. 2010/11. Wellington: Ministry for Ministry for Agriculture and Forestry Biosecurity New Zealand.

Ross, P. M., Boudry, P., Culloty, S., Michael, K., Wilkie, E., and Lane, H. (2017). Bonamia Response 2015: Report from the Technical Advisory Group on Resilience Breeding in Flat Oysters. Wellington: Ministry for Primary Industries.

Ruiz, G. M., Fofonoff, P. W., Carlton, J. T., Wonham, M. J., and Hines, A. H. (2000). Invasion of coastal marine communities in North America: apparent patterns, processes and biases. Annu. Rev. Ecol. Evol. Syst. 31, 481-531. doi: 10.1146/annurev.ecolsys.31.1.481

Scianni, C., and Georgiades, E. (2019). Vessel in-water cleaning or treatment: Identification of environmental risks and science needs for evidencebased decision making. Front. Mar. Sci. 6:467. doi: 10.3389/fmars.2019. 00467

Seaward, K., Acosta, H., Inglis, G. J., Wood, B., Riding, T., Wilkens, S., et al. (2015). The marine biosecurity porthole - a web-based information system on nonindigenous marine species in New Zealand. Manag. Biol. Invasion. 6, 177-184. doi: $10.3391 / \mathrm{mbi} .2015 .6 .2 .08$

Simkanin, C., Davidson, I. C., Dower, J. F., Jamieson, G., and Therriault, T. W. (2012). Anthropogenic structures and the infiltration of natural benthos by invasive ascidians. Mar. Ecol. 33, 499-511. doi: 10.1111/j.1439-0485.2012. 00516.x

Sim-Smith, C., Faire, S., and Lees, A. (2016). Managing Biosecurity for Business Benefit. Aquaculture Biosecurity Practices Research. Technical Paper No. 2016/14. Wellington: Ministry for Primary Industries.

Sinner, J., Forrest, B., Newton, M., Hopkins, G., Inglis, G., Woods, C., et al. (2013). Managing the Domestic Spread of Harmful Marine Organisms. Part B: Statutory Framework and Analysis Of Options. Cawthron Institute Report No. 2442, prepared for Ministry for Primary Industries. Wellington: Ministry for Primary Industries.

Skerman, T. M. (1960). Ship fouling in New Zealand waters: a survey of marine fouling organisms from vessels of the coastal and overseas trade. New Zeal. J. Sci. 3, 620-648.

Soliman, T., and Inglis, G. J. (2018). Forecasting the economic impacts of two biofouling invaders on aquaculture production of green-lipped mussels Perna canaliculus in New Zealand. Aquacult. Env. Interact. 10, 1-12. doi: 10.3354/ aei00249

South, P. M., Floerl, O., Forrest, B. M., and Thomsen, M. S. (2017). A review of three decades of research on the invasive kelp Undaria pinnatifida in Australasia: an assessment of its success, impacts and status as one of the world's worst invaders. Mar. Environ. Res. 131, 243-257. doi: 10.1016/j.marenvres. 2017.09.015

Statistics New Zealand, (2015a). Are New Zealanders Living Closer to the Coast? Wellington: Statistics New Zealand.

Statistics New Zealand, (2015b). Value of Fisheries and Aquaculture. Wellington: Statistics New Zealand.

Stubbings, H. G. (1947). Biology of the underwater fouling of ships' hulls. J. Nav. Eng. 1, 41-50.

Sylvester, F., Kalaci, O., Leung, B., Lacoursière-Roussel, A., Murray, C. C., Choi, F. M., et al. (2011). Hull fouling as an invasion vector: can simple models explain a complex problem? J. Appl. Ecol. 48, 415-423. doi: 10.1111/j.1365-2664.2011. 01957.x

Tribou, M., and Swain, G. (2017). The effects of grooming on a copper ablative coating: a six year study. Biofouling 33, 494-504. doi: 10.1080/08927014.2017. 1328596

Vaughan, L. (2008). Top of the South Marine Biosecurity Strategic Plan EP08/12/07. Report prepared for meeting of 16 December 2008. New Zealand: Nelson.

Wehi, P., Cox, M., Roa, T., and Whaanga, H. (2013). Marine resources in Māori oral tradition: he kai moana, he kai mā te hinengaro. J. Mar. Island. Cult. 2, 59-68. doi: 10.1016/j.imic.2013.11.006

Willan, R. C., Russell, B. C., Murfet, N. B., Moore, K. L., McEnnulty, F. R., Horner, S. K., et al. (2000). Outbreak of Mytilopsis sallei (Récluz, 1849) (Bivalvia: Dreissenidae) in Australia. Molluscan Res. 20, 25-30. doi: 10.1080/13235818. 2000.10673730

Woods, C., Floerl, O., Fitridge, I., Johnston, O., Robinson, R., Rupp, D., et al. (2007). Efficacy of Hull Cleaning Operations in Containing Biological Material II. Seasonal Variability. Biosecurity New Zealand Technical Paper No. 08/11. Wellington: Ministry for Primary Industries.

Woods, C., Seaward, K., Pryor Rodgers, L., Buckthought, D., Carter, M., Lyon, W., et al. (2019). Marine High Risk Site Surveillance. Annual Synopsis Report for All High Risk Sites 2018-2019. Biosecurity New Zealand Technical Paper No. 2019/31. Wellington: Ministry for Primary Industries.

Zaiko, A., Pochon, X., Garcia-Vazquez, E., Olenin, S., and Wood, S. A. (2018). Advantages and limitations of environmental DNA/RNA tools for marine biosecurity: management and surveillance of non-indigenous species. Front. Mar. Sci. 5:322. doi: 10.3389/fmars.2018.00322

Conflict of Interest: The authors declare that the research was conducted in the absence of any commercial or financial relationships that could be construed as a potential conflict of interest.

Copyright (C) 2020 Georgiades, Kluza, Bates, Lubarsky, Brunton, Growcott, Smith, McDonald, Gould, Parker and Bell. This is an open-access article distributed under the terms of the Creative Commons Attribution License (CC BY). The use, distribution or reproduction in other forums is permitted, provided the original author(s) and the copyright owner(s) are credited and that the original publication in this journal is cited, in accordance with accepted academic practice. No use, distribution or reproduction is permitted which does not comply with these terms. 